\title{
Detection of diarrhoeagenic Escherichia coli in clinical and environmental water sources in South Africa using single-step 11-gene m-PCR
}

\author{
K. B. Omar • T. G. Barnard
}

Received: 5 February 2014/ Accepted: 16 June 2014/Published online: 27 June 2014

(c) The Author(s) 2014. This article is published with open access at Springerlink.com

\begin{abstract}
Escherichia coli (E. coli) consists of commensal (ComEC) and diarrhoeagenic (DEC) groups. ComEC are detected using traditional culture methods. Conformational steps are performed after culturing if it is required to test for the presence of DEC, increasing cost and time in obtaining the results. The aim of this study was to develop a single-step multiplex polymerase chain reaction (m-PCR) that can simultaneously amplify genes associated with DEC and ComEC, with the inclusion of controls to monitor inhibition. A total of 701 samples, taken from clinical and environmental water sources in South Africa, were analysed with the optimised m-PCR which targeted the eaeA, stxl, stx2, lt, st, ial, eagg, astA and bfp virulence genes. The $m d h$ and gapdh genes were included as an internal and external control, respectively. The presence of the external control gapdh gene in all samples excluded any possible PCR inhibition. The internal control $m d h$ gene was detected in $100 \%$ of the environmental and $85 \%$ of the clinical isolates, confirming the classification of isolates as E. coli PCR positive samples. All DEC types were detected in varying degrees from the $m d h$ positive environmental and clinical isolates. Important gene code combinations were detected for clinical isolates of $0.4 \%$ lt and eagg. However, $2.3 \%$ of eaeA and ial, and $8.7 \%$ of eaeA and eagg were reported for environmental water samples. The $E$. coli ast $A$ toxin was detected as positive at 35 and $17 \%$ in environmental isolates and clinical isolates, respectively.
\end{abstract}

\footnotetext{
K. B. Omar $(\bowtie) \cdot$ T. G. Barnard

Faculty of Health Sciences, Water and Health Research Centre,

University of Johannesburg, Doornfontein,

PO Box 17011, Johannesburg 2028, South Africa

e-mail: kousaro@uj.ac.za

T. G. Barnard

e-mail: tgbarnard@uj.ac.za
}

Interestingly, $25 \%$ of the E. coli astA toxin detected in environmental isolates and $17 \%$ in clinical isolates did not contain any of the other virulence genes tested. In conclusion, the optimised single-step 11-gene m-PCR reactions could be successfully used for the identification of pathogenic and non-pathogenic E. coli types. The m-PCR was also successful in showing monitoring for PCR inhibition to ensure correct reporting of the results.

Keywords Clinical/environmental samples . Diarrhoeagenic E. coli $\cdot$ Multiplex-PCR

\section{Introduction}

Escherichia coli (E. coli) consists of both commensal (ComEC) and diarrhoeagenic (DEC) types. DEC not only indicate the presence of intestinal pathogens or parasites but also constitute a human health risk in themselves (Grabow et al. 2003; Kaper et al. 2004). At present, seven groups of pathogenic $E$. coli have been identified, of which five were selected for this study based on their importance for surface-water pathogenicity. The DEC types have been classified into the following: entero-pathogenic E. coli (EPEC), entero-toxigenic E. coli (ETEC), entero-haemorrhagic E. coli (EHEC), entero-aggregative E. coli (EAEC) and entero-invasive E. coli (EIEC) (Ashbolt 2004; Kaper et al. 2004). There are media available for the detection of specific EHEC 0157:H7 but traditional culture methods for E. coli were not designed for the detection of DEC (Iijima et al. 2007) but rather ComEC. Further conformational steps are thus required after culturing to distinguish the DEC from the ComEC which increases cost and time in producing the results. Diarrhoeagenic bacteria such as Campylobacter jejuni, Salmonella enterica serovar, 
Shigella spp., and Vibrio spp., can be readily isolated using selective plating media, with the exception of STEC 0157. Serotyping is the predominant means of differentiating pathogenic strains of $E$. coli, and phenotypic assays based on virulence characteristics can also identify DEC. Genotypic assays targeting virulence genes, especially polymerase chain reaction (PCR), are becoming standard procedure (Iijima et al. 2007).

Diagnosis is currently recommended for cases of persistent diarrhoea, children with severe diarrhoea unresponsive to treatment and immunodeficient patients with moderate to severe diarrhoea, and in epidemic outbreaks of gastroenteritis (Vidal et al. 2005). Methods in molecular biology have progressed and offer significant increases in speed and specificity in identifying micro-organisms according to their specific genetic makeup encoded in the genomic DNA (Horokova et al. 2008). Technologies such as microarrays and PCR are used to explore the global virulence pattern of strains (Wu et al. 2007). However, for developing countries microarray is an expensive method which laboratories cannot afford for routine analysis. M-PCR is a rapid and cost-effective method for screening and identifying DEC. The targets selected for each category were: EHEC (stx1, stx2 and eaeA); Atypical EPEC (eaeA) and Typical EPEC (bfp); ETEC ( $s t$ and $l t)$; EIEC (ial); EAEC (eagg); Commensal E. coli (mdh); E. coli toxin (astA) and, for the external control, gapdh.

The major obstacle to using PCR for the detection and identification of pathogenic organisms from clinical or environmental water samples is the presence of substances that are inhibitory to PCR such as humic substances (Shieh et al. 1995; Wilson 1997). In order to monitor PCR inhibition sufficient laboratory controls are required in the m-PCR. The majority of published studies report the addition of $16 \mathrm{~s}$ rRNA gene as the internal control to monitor for false negative results in m-PCR (Sabat et al. 2000; Grape et al. 2007). However, these are not sufficient to monitor false negative results for $E$. coli specifically, since $16 \mathrm{~s}$ rRNA is amplified from the $E$. coli DNA. It would not be possible to determine whether a lack of PCR amplification of 16s rRNA is as a result of PCR inhibition in the sample or is because there is no E. coli in the sample. As reported by Hartman et al. (2005), the high level of PCR sensitivity creates an elevated risk of false positive and negative results.

\section{Methodology}

The aim of this study was to develop a single-step multiplex polymerase chain reaction (m-PCR) that distinguishes selected E. coli patho-types. Internal controls were included to monitor inhibition in each sample thereby indicating false positive or false negative results.

Growth and maintenance of bacterial strains

Thirty-eight bacterial strains, which included commensal and pathogenic E. coli strains, Shigella spp., Salmonella spp., Vibrio spp. [obtained from National Health laboratory services (NHLS); (Table 1)] and other strains of the Enterobacteriaceae family such as Klebsiella spp., Aeromonas spp., Pseudomonas aeruginosa, Bacillus subtilis, Bacillus cereus, Enterococcus spp. and Morganella morganni (obtained from undergraduate practical laboratory) were cultured on Plate Count Agar (PCA) (Oxoid, UK) and incubated under aerobic conditions at $37{ }^{\circ} \mathrm{C}$ for $16 \mathrm{~h}$. Single colonies were enriched in nutrient broth (Oxoid, UK) and incubated under aerobic conditions at $37{ }^{\circ} \mathrm{C}$ for $16 \mathrm{~h}$. The commensal E. coli strain was used as the positive control. Klebsiella pneumoniae (KLEPN 01) and Pseudomonas aeruginosa (PSEAE 01) were used as the negative controls for the Colilert ${ }^{\circledR}$ Quanti-Trays ${ }^{\circledR} / 2000$.

M-PCR testing on enriched environmental water samples and isolates

Once the m-PCR was developed it was tested on clinical, environmental isolates and environmental water samples.

Microbial analysis

\section{Clinical isolates}

239 clinical isolates were obtained from Ampath Laboratory (Pretoria). Single colonies which were confirmed

Table 1 Bacterial strains used in molecular characterisation

\begin{tabular}{|c|c|c|}
\hline Bacterial strain & Reference nr & Genes present \\
\hline $\begin{array}{l}\text { Escherichia coli } \\
\left(_{(\text {Commensal })^{\mathrm{a}}}\right.\end{array}$ & ATCC 25922 & $m d h$ \\
\hline $\begin{array}{l}\text { Enterohaemorrhagic } \\
\text { (EHEC) }\end{array}$ & ESCCO $21^{\mathrm{b}}$ & $\begin{array}{l}m d h, \text { stx } 1, \text { stx } 2 \text { and } \\
\quad e a e A\end{array}$ \\
\hline Enteroinvasive (EIEC) & $\begin{array}{l}\text { ESCCOS ATCC } \\
43893^{\mathrm{b}}\end{array}$ & $m d h$ and $i a l$ \\
\hline Enterotoxigenic (ETEC) & $\operatorname{ESCCO} 22^{\mathrm{b}}$ & $m d h, l t$ and $s t$ \\
\hline $\begin{array}{l}\text { Enteropathogenic } \\
\text { (EPEC) }\end{array}$ & S-ESCCO $16 \mathrm{Pl}^{\mathrm{b}}$ & $m d h, e a e A, b f p$ \\
\hline $\begin{array}{l}\text { Enteroaggregative } \\
\text { (EAEC) }\end{array}$ & ESCCO $14^{\mathrm{b}}$ & $m d h$ and eagg \\
\hline
\end{tabular}

\footnotetext{
${ }^{a}$ Environmental isolate confirmed by API 20E (OMNIMED $\left.{ }^{\circledR}\right)$ and PCR as commensal E. coli

b Strains purchased from National Health Laboratory Services (NHLS)
} 
E. coli positive by Ampath Laboratory were enriched as described above (growth and maintenance).

\section{Environmental isolates}

171 environmental water samples (container water, toilet seats, borehole, stream, river) were collected in $11 \mathrm{sam}$ pling bottles and stored at $4{ }^{\circ} \mathrm{C}$ on route to the laboratory. The water samples $(100 \mathrm{ml})$ were filtered onto $0.45 \mu \mathrm{m}$ gridded nitro-cellulose membranes (NC) (Merck, Germany) using the standard membrane filtration technique, placed onto E. coli/Coliform Chromogenic Media (Oxoid, UK) and incubated under aerobic conditions at $37{ }^{\circ} \mathrm{C}$ for $16 \mathrm{~h}$ (Standard Methods 2005). Single colonies that appear purple on the selective E. coli media were enriched as described above in growth and maintenance.

\section{Environmental water samples}

291 water samples (Waste water: upstream, downstream and final effluent) were collected in 11 sampling bottles and stored at $4{ }^{\circ} \mathrm{C}$ on route to the laboratory. The water samples were immediately analysed upon arrival at the laboratory for bacterial quality using the Colilert ${ }^{\circledR}$ QuantiTray ${ }^{\circledR} / 2000$ system (IDDEX). Enumeration of $E$. coli from water was done using $100 \mathrm{ml}$ water according to the manufacturer's instructions. The Quanti-Trays ${ }^{\circledR}$ were incubated for $18 \mathrm{~h}$ at $35^{\circ} \mathrm{C}$. After incubation, the QuantiTrays ${ }^{\circledR} / 2000$ were examined under long wave $(366 \mathrm{~nm})$ ultraviolet light, and wells that turned both yellow and fluoresced were counted as E. coli positive (IDDEX).

\section{DNA extraction}

\section{Clinical and environmental isolates}

$2 \mathrm{ml}$ of the enriched single colony was centrifuged for $2 \mathrm{~min}$ at $13,000 \times \mathrm{g}$ to pellet the cells and the supernatant was discarded. DNA was extracted from the collected bacterial cells using the silica/guanidium thiocyanate method reported by Boom et al. (1990) as well as adaptations of spin columns reported on by Borodina et al. (2003). The adjustments included the addition of $250 \mu \mathrm{l}$ $100 \%$ ethanol to the lysis buffer to enhance the binding of DNA to the Celite. The Celite containing the bound DNA was loaded onto a DNA binding membrane (Borodina et al. 2003) in the spin columns. DNA was eluted with $100 \mu \mathrm{l}$ Qiagen elution buffer (Southern Cross Biotechnology ${ }^{\circledR}$ ) [Omar et al. (2010)]. The extracted DNA was used as a template in all PCR reactions.

\section{Colilert $^{\circledR}$ Quanti-Trays $^{\circledR} / 2000$ system}

A total of $2 \mathrm{ml}$ of the media was removed from up to ten positive E. coli wells of the Colilert ${ }^{\circledR}$ Quanti-Trays ${ }^{\circledR} / 2000$ using sterile $1 \mathrm{ml}$ Neomedic disposable syringes with mounted needle (Kendon Medical Supplies) and aliquoted into $2 \mathrm{ml}$ sterile Eppendorf tubes. The tubes were centrifuged for $2 \mathrm{~min}$ at $13,000 \times g$ to pellet the cells and the supernatant discarded. DNA was extracted from the collected bacterial cells as explained above and as reported by Omar et al. (2010). The extracted DNA was used as a template in all PCR reactions.

Multiplex polymerase chain reaction (m-PCR)

All m-PCR reactions were performed in a Biorad Mycy$\operatorname{cler}^{\mathrm{TM}}$ thermal cycler in a total reaction volume of $20 \mu \mathrm{l}$. A hotstart multiplex PCR kit $\left(\right.$ Qiagen $\left.{ }^{\circledR}\right)$ was used for the m-PCR protocol. Each reaction consisted of 1X Qiagen ${ }^{\circledR}$ PCR multiplex mix (containing HotstartTaq ${ }^{\circledR}$ DNA polymerase, multiplex PCR buffer and dNTP mix); $2 \mu$ of the primer mixture $[0.1 \mu \mathrm{M}$ of $m d h$ and $l t$ primers [Forward (F) and reverse (R)], $0.2 \mu \mathrm{M}$ of ial, eagg primers, ast $A$ primers, $b f p$ primers and gapdh primers ( $\mathrm{F}$ and $\mathrm{R}), 0.3 \mu \mathrm{M}$ of eaeA and stx2 primers (F and R), $0.5 \mu \mathrm{m}$ of $s t x 1$ and $s t$ primers [F and R (Table 2)]; $2 \mu \mathrm{l}$ of sample DNA, $1 \mu \mathrm{l}$ of gapdh cDNA and $5 \mu \mathrm{l} \mathrm{PCR}$ grade water. The reactions were subjected to an initial activation step at $95^{\circ} \mathrm{C}$ for $15 \mathrm{~min}$, followed by 35 cycles consisting of denaturing at $94{ }^{\circ} \mathrm{C}$ for $45 \mathrm{~s}$, annealing at $55^{\circ} \mathrm{C}$ for $45 \mathrm{~s}$, extension at $68{ }^{\circ} \mathrm{C}$ for $2 \mathrm{~min}$ and final elongation at $72{ }^{\circ} \mathrm{C}$ for $5 \mathrm{~min}$.

DNA was visualised using a $2.5 \%(\mathrm{w} / \mathrm{v})$ agarose gel in TAE buffer ( $40 \mathrm{mmol} \mathrm{l}^{-1}$ Tris acetate; $2 \mathrm{mmol} \mathrm{l}^{-1}$ EDTA, $\mathrm{pH}$ 8.3) with $0.5 \mu \mathrm{g} \mathrm{ml}^{-1}$ ethidium bromide. Electrophoresis was done for $1-2 \mathrm{~h}$ in electric field strength of $8 \mathrm{~V} \mathrm{~cm}^{-1}$ gel and the DNA visualized with UV light (Syngene, UK). This procedure was followed for all the experiments except where stated differently. The relative sizes of the DNA fragments were estimated by comparing their electrophoretic mobility with that of the standards run with the samples on each gel, either a $1 \mathrm{kB}$ or $100 \mathrm{bp}$ markers (Fermentas, US).

\section{Specificity of the m-PCR}

The specificity of the m-PCR was assessed by testing 38 bacterial strains which included commensal and pathogenic E. coli strains, Shigella spp., Salmonella spp. and serovar, Vibrio spp. and other strains of the Enterobacteriaceae family such as Klebsiella spp., Aeromonas spp., Pseudomonas aeruginosa, Bacillus subtilis, Bacillus cereus, Enterococcus spp. and Morganella morgannii (Table 3). 
Table 2 Primers used in the m-PCR reaction

\begin{tabular}{|c|c|c|c|c|c|}
\hline Pathogen & Primer & Sequence $\left(5^{\prime}-3^{\prime}\right)$ & Size (bp) & Conc. $(\mu \mathrm{M})$ & Reference \\
\hline E. coli & $\begin{array}{l}m d h(F) \\
m d h(R)\end{array}$ & $\begin{array}{l}\text { GGT ATG GAT CGT TCC GAC CT } \\
\text { GGC AGA ATG GTA ACA CCA GAG T }\end{array}$ & 304 & 0.1 & Tarr et al. (2002) \\
\hline EIEC & $\begin{array}{l}\text { ial }(F) \\
\text { ial }(R)\end{array}$ & $\begin{array}{l}\text { GGT ATG ATG ATG ATG AGT CCA } \\
\text { GGA GGC CAA CAA TTA TTT CC }\end{array}$ & 650 & 0.2 & López-Saucedo et al. (2003) \\
\hline $\begin{array}{l}\text { EHEC/Atypical } \\
\text { EPEC }\end{array}$ & $\begin{array}{l}e a e A(F) \\
e a e A(R)\end{array}$ & $\begin{array}{l}\text { CTG AAC GGC GAT TAC GCG AA } \\
\text { CCA GAC GAT ACG ATC CAG }\end{array}$ & 917 & 0.3 & Aranda et al. (2004) \\
\hline Typical EPEC & $\begin{array}{l}\text { bfpA }(F) \\
\operatorname{bfp} M(R)\end{array}$ & $\begin{array}{l}\text { AAT GGT GCT TGC GCT TGC TGC } \\
\text { TAT TAA CAC CGT AGC CTT TCG CTG } \\
\text { AAG TAC CT }\end{array}$ & 410 & 0.3 & $\begin{array}{l}\text { Aranda et al. (2004) } \\
\text { From this study }\end{array}$ \\
\hline EAEC & $\begin{array}{l}\operatorname{eagg}(F) \\
\operatorname{eagg}(R)\end{array}$ & $\begin{array}{l}\text { AGA CTC TGG CGA AAG ACT GTA TC } \\
\text { ATG GCT GTC TGT AAT AGA TGA GAA C }\end{array}$ & 194 & 0.2 & Pass et al. (2000) \\
\hline EHEC & $\begin{array}{l}\text { stxl }(F) \\
\operatorname{stx} 1(R)\end{array}$ & $\begin{array}{l}\text { ACA CTG GAT GAT CTC AGT GG } \\
\text { CTG AAT CCC CCT CCA TTA TG }\end{array}$ & 614 & 0.5 & Moses et al. (2006) \\
\hline & $\begin{array}{l}\operatorname{stx} 2(F) \\
\operatorname{stx} 2(R)\end{array}$ & $\begin{array}{l}\text { CCA TGA CAA CGG ACA GCA GTT } \\
\text { CCT GTC AAC TGA GCA CTT TG }\end{array}$ & 779 & 0.3 & Moses et al. (2006) \\
\hline ETEC & $\begin{array}{l}\text { lt }(F) \\
\text { lt }(R)\end{array}$ & $\begin{array}{l}\text { GGC GAC AGA TTA TAC CGT GC } \\
\text { CGG TCT CTA TAT TCC CTG TT }\end{array}$ & 360 & 0.1 & Pass et al. (2000) \\
\hline & $\begin{array}{l}\text { st }(F) \\
\text { st }(R)\end{array}$ & $\begin{array}{l}\text { TTT CCC CTC TTT TAG TCA GTC AAC TG } \\
\text { GGC AGG ATT ACA ACA AAG TTC ACA }\end{array}$ & 160 & 0.5 & Pass et al. (2000) \\
\hline E. coli toxin & $\begin{array}{l}\operatorname{astA}(F) \\
\operatorname{astA}(R)\end{array}$ & $\begin{array}{l}\text { GCC ATC AAC ACA GTA TAT CC } \\
\text { GAG TGA CGG CTT TGT AGT C }\end{array}$ & 106 & 0.3 & Kimata et al. (2005) \\
\hline External control & $\begin{array}{l}\operatorname{gapdh}(F) \\
\operatorname{gapdh}(R)\end{array}$ & $\begin{array}{l}\text { GAG TCA ACG GAT TTG GTC GT } \\
\text { TTG ATT TTG GAG GGA TCT CG }\end{array}$ & 238 & 0.3 & Mbene et al. (2009) \\
\hline
\end{tabular}

NB: $F$ forward primer, $R$ reverse primer

\section{Results and discussion}

The main challenge of designing a multiplex PCR is the possibility of primer dimers and non-specific results which is a risk for false positive and negative results. Therefore, it is necessary to design and include primers with close annealing temperatures and to begin the program with a hotstart as reported by Vidal et al. (2005). The effect of the wide temperature range is overcome by the addition of Q-solution that is supplied by the manufacturer and that can be included with the enzyme. A wide variety of temperatures were tested before the final version of the multiplex PCR was optimized and tested. The results confirm that the single m-PCR was successfully compiled to detect all of the targeted genes in a single reaction even though primers with different melting temperatures ranging from 50 to $73{ }^{\circ} \mathrm{C}$ were used (Fig. 1). The PCR amplicons were confirmed as the correct target gene by sequencing (data not shown) showing the specific amplification of the genes in a mixture of DEC.

Specificity of the m-PCR

The specificity of the m-PCR was tested on 38 laboratory bacterial strains. Specificity was stated by Aldrich and
Griffith (2003) as 'the ability of the assay to detect a unique event to the exclusion of all other events'; that is, to what extent can the assay detect a specific pathobiologic effect that will exclude all other similar pathobiologic effects. Positive PCR results were only obtained for the E. coli and Shigella strains (Table 3). However, the $m d h$ gene was not detected for Shigella boydii serotype B. Boerlin et al. (1999) state that Shigella is similar to EIEC and the stxl is almost identical to the shiga toxin of Shigella dysenteriae in amino acid sequence and cannot be distinguished from serologically, yet ial and eaeA were detected for Shigella sonnei. No positive PCR results were obtained for the DNA from the other bacterial strains tested. Specific genes were detected for each patho-type as indicated in Table 1; there was no cross reactivity of genes between patho-types. No false positives and no PCR inhibition were obtained due to the external control gapdh gene that was detected in $100 \%$ $(38 / 38)$ of the samples.

\section{Application}

A total of 701 samples were analysed, samples composed of 239 clinical isolates, 171 environmental water isolates and 291 samples from the Colilert ${ }^{\circledR}$ Quanti-Tray ${ }^{\circledR} / 2000$ (Fig. 2); these samples were obtained from various 
Table 3 Specificity of the m-PCR

\begin{tabular}{|c|c|c|c|c|c|c|c|c|c|c|c|c|}
\hline \multirow[t]{2}{*}{ Bacterial strain } & \multirow[t]{2}{*}{ Source } & \multicolumn{11}{|c|}{ Genes } \\
\hline & & $m d h$ & $e a e A$ & $b f p$ & stxl & stx 2 & ial & $l t$ & gapdh & st & eagg & astA \\
\hline Commensal E. coli & NHLS & + & - & - & - & & - & - & + & - & - & - \\
\hline Enterohaemorrhagic $E$. coli & NHLS & + & + & - & + & + & - & - & + & - & - & - \\
\hline Enteropathogenic E. coli & NHLS & + & + & + & - & - & - & - & + & - & - & + \\
\hline Enteroaggregative $E$. coli & NHLS & + & - & - & - & - & - & - & + & - & + & - \\
\hline Enterotoxigenic $E$. coli & NHLS & + & - & - & - & - & - & + & + & + & - & - \\
\hline Enteroinvasive $E$. coli & NHLS & + & - & - & - & - & + & - & + & - & - & - \\
\hline Shigella dysenteriae serovar type 1 & NHLS & + & - & - & - & - & + & - & + & - & - & - \\
\hline Shigella dysenteriae serovar type 2 & NHLS & + & - & - & - & - & + & - & + & - & - & - \\
\hline Shigella boydii serovar B & NHLS & - & - & - & - & - & - & - & + & - & - & - \\
\hline Shigella flexneri & NHLS & + & - & - & - & - & - & - & + & - & - & - \\
\hline Shigella sonnei & NHLS & + & + & - & - & - & + & - & + & - & - & - \\
\hline Vibrio cholerae non-O1 & NHLS & - & - & - & - & - & - & - & + & - & - & - \\
\hline Vibrio cholerae $\mathrm{O} 1$ & NTCC & - & - & - & - & - & - & - & + & - & - & - \\
\hline Vibrio cholerae $\mathrm{O} 1$ & NTCC & - & - & - & - & - & - & - & + & - & - & - \\
\hline Vibrio parahaemolyticus & NHLS & - & - & - & - & - & - & - & + & - & - & - \\
\hline Vibrio parahaemolyticus & NCTC & - & - & - & - & - & - & - & + & - & - & - \\
\hline Vibrio cholerae $\mathrm{O} 139$ & NHLS & - & - & - & - & - & - & - & + & - & - & - \\
\hline Vibrio cholerae Ogawa & NHLS & - & - & - & - & - & - & - & + & - & - & - \\
\hline Vibrio mimicus & NHLS & - & - & - & - & - & - & - & + & - & - & - \\
\hline Vibrio fluvialis & NCTC & - & - & - & - & - & - & - & + & - & - & - \\
\hline Vibrio furnissii & ATCC & - & - & - & - & - & - & - & + & - & - & - \\
\hline Salmonella enterica serovar Typhi salty $\mathrm{O} 1$ & NHLS & - & - & - & - & - & - & - & + & - & - & - \\
\hline Salmonella enterica serovar Typhimurium saltm $\mathrm{O} 1$ & NHLS & - & - & - & - & - & - & - & + & - & - & - \\
\hline Salmonella enterica serovar Typhimurium saltm O2 & NHLS & - & - & - & - & - & - & - & + & - & - & - \\
\hline Salmonella enterica serovar Typhi salty $\mathrm{O} 2$ & NHLS & - & - & - & - & - & - & - & + & - & - & - \\
\hline Salmonella enterica serovar Paratyphi & NHLS & - & - & - & - & - & - & - & + & - & - & - \\
\hline Salmonella enterica serovar Paratyphi A & NHLS & - & - & - & - & - & - & - & + & - & - & - \\
\hline Salmonella enterica serovar Paratyphi C & NHLS & - & - & - & - & - & - & - & + & - & - & - \\
\hline Salmonella Gallinarum & NHLS & - & - & - & - & - & - & - & + & - & - & - \\
\hline Salmonella enterica serovar Enteritidis & NHLS & - & - & - & - & - & - & - & + & - & - & - \\
\hline Pseudomonas aeruginosa & NHLS & - & - & - & - & - & - & - & + & - & - & - \\
\hline Klebsiella pneumonia & NHLS & - & - & - & - & - & - & - & + & - & - & - \\
\hline Bacillus subtilis & NHLS & - & - & - & - & - & - & - & + & - & - & - \\
\hline Bacillus cereus & NHLS & - & - & - & - & - & - & - & + & - & - & - \\
\hline Aeromonas veronii & ATCC & - & - & - & - & - & - & - & + & - & - & - \\
\hline Enterococcus faecium & NHLS & - & - & - & - & - & - & - & + & - & - & - \\
\hline Enterococcus faecalis & NHLS & - & - & - & - & - & - & - & + & - & - & - \\
\hline Morganella morgannii & NHLS & - & - & - & - & - & - & - & + & - & - & - \\
\hline
\end{tabular}

provinces in South Africa. Isolates and water samples were subjected to the protocols described in the methodology, with $100 \%(171 / 171)$ of environmental water isolates, $85 \%(202 / 239)$ of the clinical isolates and $100 \%$ (291/ 291) of the water samples testing positive for the $m d h$ house-keeping gene (Fig. 2). For the $15 \%$ (37/239) of clinical isolates in which the $m d h$ gene was not detected, it is possible that these do not contain the malate dehydrogenase but the malic acid dehydrogenase gene, which is also a housekeeping enzyme of the citric acid cycle (Hsu and Tsen 2001). When the study was initiated Tarr et al. (2002) article was used, who included the malate dehydrogenase gene and indicated in their tests positive results for all the $E$. coli strains tested. Based on this the $m d h$ gene was used as a control to confirm the microbiology results in case no pathogenic genes tested for were 


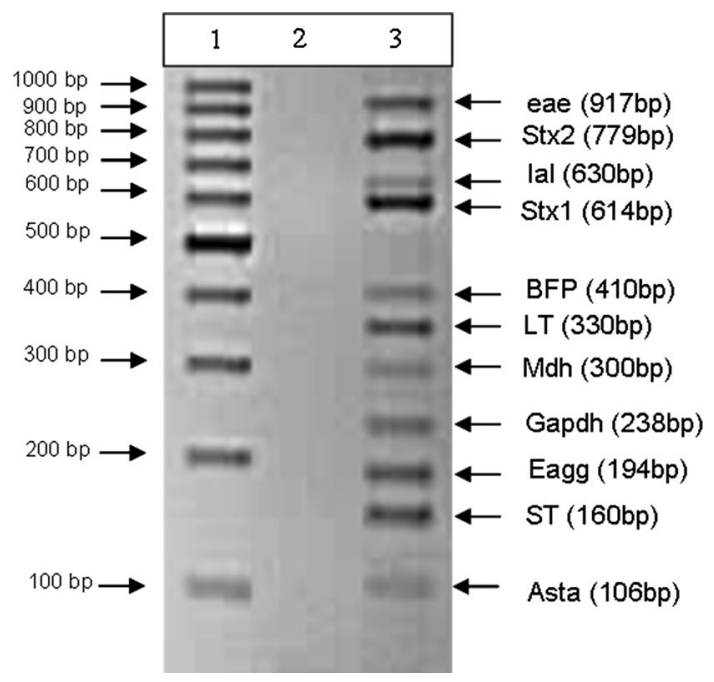

Fig. 1 Agarose gel of the PCR products obtained for the E. coli multiplex PCR (lane 2). No template control (NTC) in (lane 2). The molecular weight marker is shown in (lane 1)

detected. It is only later that for a separate study the malic acid dehydrogenase gene was tested (also referred to as $m d h$ by Hsu and Tsen 2001) that not all the E. coli strains present in the samples tested positive. The reason could be that the original work by the authors were done on strains that could not be present in South Africa or that we have strains that have different genetic characteristics. No false positives and no PCR inhibition were indicated in the $\mathrm{m}-\mathrm{PCR}$ as the external control gene ( gapdh) was detected in $100 \%(701 / 701)$ of the samples. A supposedly negative test result for an infectious agent can influence therapeutic decisions, such as withholding antibiotic and antiviral drugs (Cone et al. 1992; Hartman et al. 2005). Therefore, the additions of the internal and external controls are important to ensure that there are no PCR inhibitors in the reaction as well as to validate the accuracy of the PCR in distinguishing false negative from true negative PCR results.

\section{Environmental water isolates}

Of the E. coli positive environmental water isolates (171) tested, eagg gene (EAEC), ial gene (EIEC), st and $l t$ genes (ETEC), stxl gene and stx2 gene, eaeA gene (EHEC, Atypical-EPEC) tested positive (see Table 4 for the percentages of each gene). Positive gene combinations detected for eaeA and stxl 2.3, $0.6 \%$ combination of $e a e A$, stx 1 and stx2 (EHEC). Literature states that $s t x 1$ and/or stx2 can be detected individually or in combination due to being phage-encoded (Müller et al. 2001; Contreras et al. 2011; Feng et al. 2011). To discriminate between typical and atypical EPEC, $29.8 \%$ tested positive for the $e a e A$ and $b f p$ gene (Typical-EPEC), $3.5 \%$ bfp gene (Typical-EPEC) and $27 \%$ eaeA gene (Atypical EPEC). For the astA gene (E. coli toxin) $25 \%$ was detected without the combination of the virulence genes. The distribution of the astA toxin gene combined with the virulence genes is indicated in Table 6. Interesting results was $2.3 \%$ combination of eaeA and ial as well as combination of eaeA and eagg $8.7 \%$ (Table 5). Literature reports gene coding of eaeA with EHEC and EPEC (Presterl et al. 2003; Müller et al. 2001; Aranda et al. 2004; Moses et al. 2006) but not with eagg and ial. Published reports have described eaeA as the bacterial outer membrane protein intimin, which is essential in organizing host cytoskeletal rearrangements and generating the pedestal-like structure in which the bacteria reside. Intimin is required for full bacterial virulence and its expression is regulated by the per regulon. The per regulon comprises four reading frames (perA, $B, C$ and $D$ ), and maximal expression requires all four gene products, however, expression of perC alone can induce intimin expression (Kenny et al. 1997). The question is has intimin been expressed from EAEC and EIEC? Or as Chen and Dubnau (2004) reported that DNA can be transferred from one organism to another via conjugation. They also reported DNA can be actively secreted by viable organisms. Hacker and Kaper (2000) reported that free DNA released from dead bacteria can be taken up by bacteria in the environment via natural transformation and may carry pathogenicity islands (PAIs). The majority of PAIs are located on the chromosome, but can also be part of bacterial plasmids and phages. More research has to be conducted to determine these gene-coding combinations.

\section{Clinical isolates}

Of the clinical isolates (239) tested, eagg (EAEC), $l t$ and $s t$ (ETEC), eaeA and stx2 (EHEC, Atypical-EPEC) tested positive (Table 4). Positive gene combinations were detected for $0.8 \%$ eaeA and $b f p$ (Typical-EPEC), $0.8 \%$ $b f p$ (Typical-EPEC) and $13.4 \%$ eaeA gene (Atypical EPEC), $17 \%$ astA (E. coli toxin). The significance of differentiating between typical and atypical EPEC is that atypical EPEC are more frequently isolated from diarrhoea cases than typical EPEC. However, while typical EPEC dominates in developing countries, atypical EPEC has also been shown to cause large outbreaks involving both children and adults (Kaper et al. 2004). For the astA gene (E. coli toxin) $78 \%$ was detected without the combination of the virulence genes. The distribution of the astA toxin gene combined with the virulence genes is indicated in Table 6. This result is very important: Hidaka et al. (2009) reported that a 1996 outbreak of gastrointestinal illness was caused by E. coli 0166:H15 which possessed no 


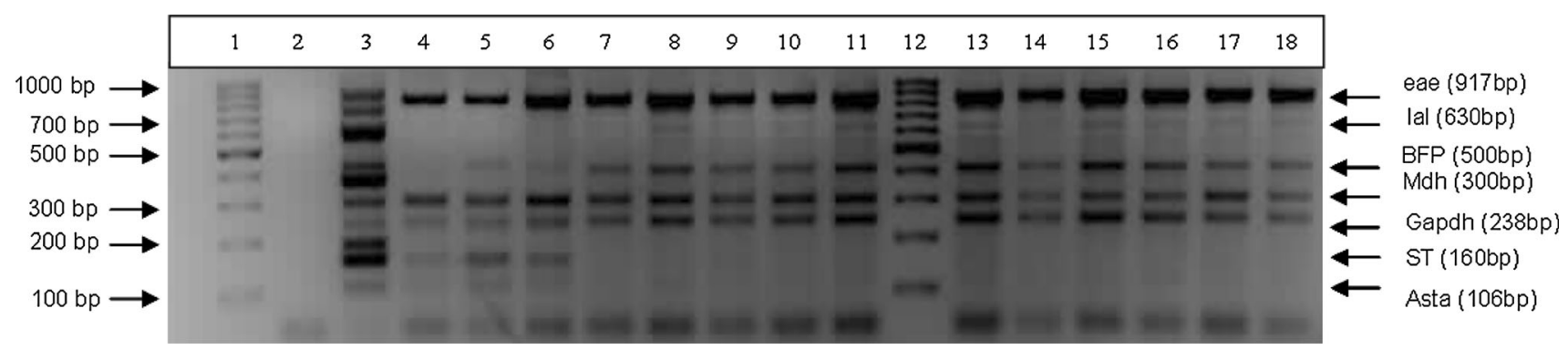

Fig. 2 Agarose gel of the PCR products obtained from samples (lane 4-11, 13-18). No template control (NTC) in (lane 2). The molecular weight marker is shown in (lane 1 and 12). The positive reference control is shown in (lane 3)

Table 4 PCR results obtained from the single isolates of the clinical and environmental isolates and water samples from the Colilert ${ }^{\circledR}$ QuantiTray ${ }^{\circledR} / 2000$

\begin{tabular}{|c|c|c|c|c|c|c|c|c|c|c|c|c|}
\hline \multirow[b]{3}{*}{ Sample type } & \multirow[b]{3}{*}{$\mathbf{n}$} & \multicolumn{5}{|c|}{ EHEC } & \multirow{2}{*}{\multicolumn{2}{|c|}{ ETEC }} & \multirow{3}{*}{$\frac{\text { Eagg }}{\text { eagg }}$} & \multirow{3}{*}{$\frac{\text { EIEC }}{\text { ial }}$} & \multirow[b]{3}{*}{ asta } & \multirow[b]{3}{*}{ gapdh } \\
\hline & & \multirow{2}{*}{$\begin{array}{c}\text { HKG } \\
m d h(\%)\end{array}$} & \multicolumn{2}{|c|}{ EPEC } & \multirow[b]{2}{*}{ stx 1} & \multirow[b]{2}{*}{ stx2 } & & & & & & \\
\hline & & & bfp & eaeA & & & It & st & & & & \\
\hline Clinical isolates & 239 & $202(85)$ & $4(2)$ & $35(15)$ & $0(0)$ & $1(0)$ & $15(6)$ & $6(3)$ & $3(1)$ & $0(0)$ & $41(17)$ & $239(100)$ \\
\hline Environmental isolates & 171 & $171(100)$ & $57(33)$ & $98(57)$ & $6(4)$ & $2(1)$ & $9(5)$ & $6(4)$ & $27(16)$ & $6(4)$ & $60(35)$ & $171(100)$ \\
\hline Environmental water & 291 & $291(100)$ & $74(25)$ & $115(40)$ & $10(3)$ & $26(9)$ & $25(9)$ & $8(3)$ & $102(35)$ & $7(2)$ & $123(42)$ & $291(100)$ \\
\hline
\end{tabular}

Table 5 Gene combinations from clinical and environmental isolates

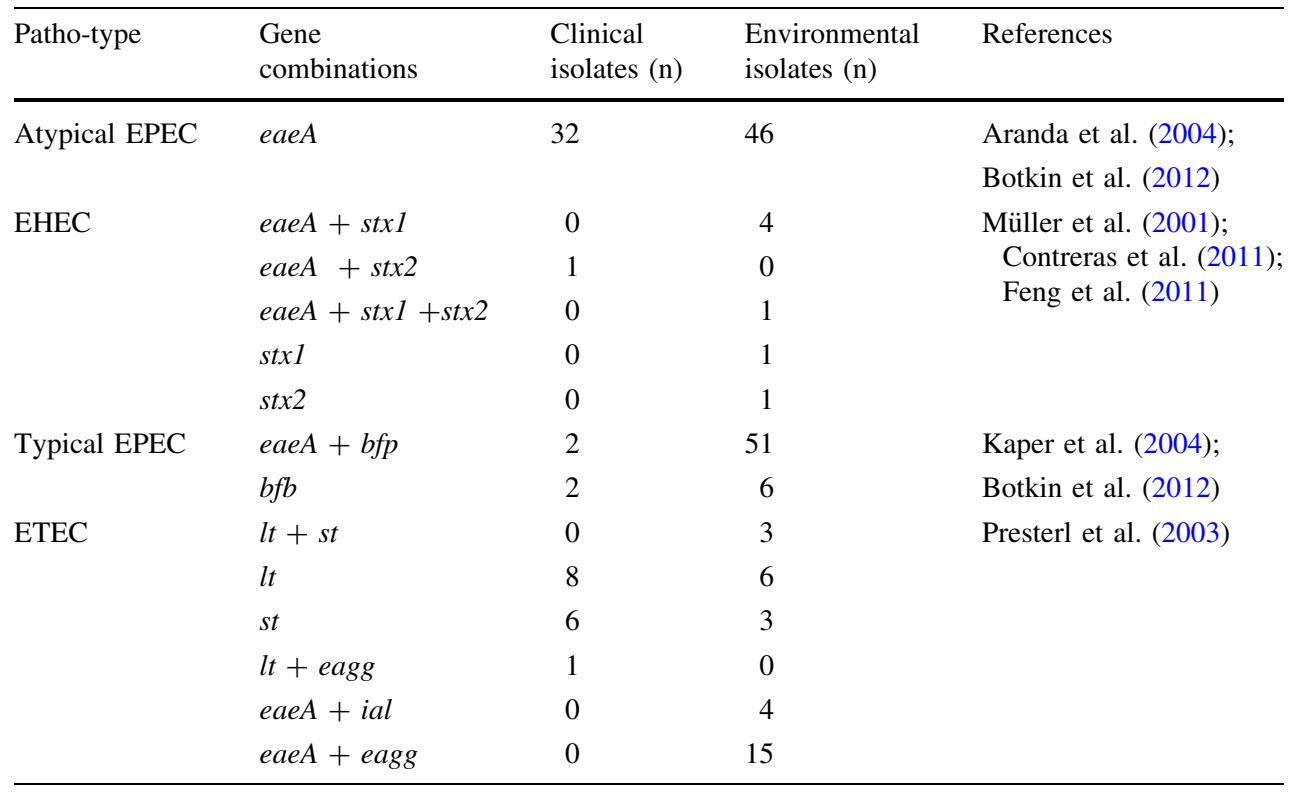

enteropathogenicity-associated genes other than the astA gene. The astA gene was first identified in EAEC as a structural gene that encodes a distinct low-molecularweight putative enterotoxin (Yatsuyanagi et al. 2003). Reports from Soto et al. (2009) indicate that the enteroaggregative heat stable toxin 1 (EAST-1) is encoded by the astA gene. This toxin is thought to play a role in EAEC pathogenicity. The toxin binds to the receptor and activates guanylate cyclise, which stimulates production of cyclic
GMP (cGMP). High levels of cGMP in the cell inhibit the $\mathrm{Na} / \mathrm{Cl}$ co-transport system, reduce the absorption of electrolytes and water from the intestine at villus tips and result in an elevated secretion of $\mathrm{Cl}^{-}$and water in crypt cells. The role of this toxin in the development of diarrhoea has yet to be defined (Soto et al. 2009). However, recently the astA gene has been detected not only in EAEC but also in EPEC, atypical EPEC, ETEC and EIEC strains (Yatsuyanagi et al. 2003). As discussed above, an interesting 
Table 6 Distribution of the astA toxin gene combined with the virulence genes for isolates, environmental isolates and water samples

\begin{tabular}{|c|c|c|c|c|c|c|c|c|c|}
\hline \multirow[b]{3}{*}{ Sample type } & \multirow[b]{3}{*}{$\mathbf{n}$} & \multicolumn{4}{|c|}{ EHEC } & \multirow{2}{*}{\multicolumn{2}{|c|}{ ETEC }} & \multirow{3}{*}{$\begin{array}{l}\text { Eagg } \\
\text { eagg }\end{array}$} & \multirow{3}{*}{$\frac{\text { EIEC }}{\text { ial }}$} \\
\hline & & \multicolumn{2}{|c|}{ EPEC } & \multirow[b]{2}{*}{ stx1 } & \multirow[b]{2}{*}{ stx2 } & & & & \\
\hline & & bfp (\%) & $e a e A$ & & & It & st & & \\
\hline Environmental isolates & 171 & $5(3)$ & $106(62)$ & $9(5)$ & $0(0)$ & $17(10)$ & $3(1.7)$ & $34(20)$ & $12(6.7)$ \\
\hline Clinical isolates & 239 & $0(0)$ & $36(15)$ & $0(0)$ & $0(0)$ & $12(5)$ & $6(2.4)$ & $6(2.4)$ & $0(0)$ \\
\hline Environmental water & 291 & 37 (12.7) & $56(24.4)$ & $3(1)$ & $4(1.4)$ & $9(3.1)$ & $4(1.4)$ & $70(24.1)$ & $5(1.7)$ \\
\hline
\end{tabular}

gene-coding combination was detected in the clinical isolates, $0.4 \%$ lt and eagg genes.

\section{Environmental water samples}

Of the $E$. coli positive environmental water samples from the Colilert ${ }^{\circledR}$ Quanti-Tray ${ }^{\circledR} / 2000$ (291) tested, presence of eagg gene (EAEC), ial gene (EIEC), lt gene and st gene (ETEC) tested positive (Table 4). Positive gene combination detected for $0.3 \%$ of $e a e A$ and $s t x l, 5.8 \%$ combination of eaeA and stx2 (EHEC), $3.1 \%$ combination of eaeA, stxl and $s t x 2$ (EHEC). To discriminate between typical and atypical EPEC $24.1 \%$ tested positive for the eaeA and $b f p$ gene (Typical-EPEC) and $1.4 \%$ bfp gene (Typical-EPEC) $17 \%$ eaeA gene (Atypical EPEC). For the astA gene (E. coli toxin) $40 \%$ was detected without the combination of the virulence genes and the distribution of the ast toxin gene combined with the virulence genes are indicated in Table 6 .

\section{Conclusion}

Both internal controls for m-PCR were used to monitor PCR inhibition that might occur due to the nature of the samples. The PCR was designed so that the gapdh gene would only be amplified in samples where no other PCR products were amplified. All the genes tested for could be detected using m-PCR with no non-specific amplification of genes. Atypical and typical EPEC could be successfully distinguished using single m-PCR reaction. The astA toxin gene was detected in both DEC and ComEC samples. Important gene combinations were detected. The m-PCR offers the user a fast and effective method to perform a simultaneous amplification not only for the detection of virulence genes from all categories of diarrhoeagenic E. coli (ETEC, typical or atypical EPEC, EIEC, EAEC, EHEC) but also commensal E. coli and internal controls to monitor for PCR inhibition. The m-PCR is easy to perform, sensitive, requires minimal specialized equipment or training, and provides same-day results necessary for rapid action in the case of diarrhoeal outbreaks.
Acknowledgments Funding obtained from the University of Johannesburg and National Research Foundation (South Africa) to complete this study. Ampath Laboratories (Pretoria) for providing the clinical isolates. The authors would like to acknowledge the publication workshop arranged by the South African Young Water Professionals during which this manuscript was prepared. We would also like to convey our appreciation to the Department of Science and Technology, Water Institute of Southern Africa and the University of Johannesburg for covering the costs of the workshop.

Open Access This article is distributed under the terms of the Creative Commons Attribution License which permits any use, distribution, and reproduction in any medium, provided the original author(s) and the source are credited.

\section{References}

Aldrich TE, Griffith J (2003) Environmental epidemiology and risk assessment. Wiley, New Jersey

Aranda KRS, Fagundes- Neto U, Scaletsky ICA (2004) Evaluation of multiplex PCR's for diagnosis of infection with diarreagenic Escherichia coli and Shigella spp. J Clin Microbiol 42:5849-5853

Ashbolt JH (2004) Microbial contamination of drinking water and disease outcomes in developing regions. Toxicology 198:229-238

Boerlin P, McEwen SA, Boerlin-Petzold F, Wilson JB, Jonson RP, Gyles CL (1999) Association between virulence factors of the shiga-toxin producing Escherichia coli and disease in humans. J Clin Microbiol 37:497-503

Boom R, Sol CJA, Salimans MMM, Jansen CL, Wertheim-Van Dillen PME, Van Der Noordaa J (1990) Rapid and simple method for purification of nucleic acids. J Clin Microbiol 28:495-503

Borodina TA, Lehrach H, Soldatov AV (2003) DNA purification on homemade silica spin columns. J Anal Biochem 321:135-137

Botkin DJ, Galli L, Sankarapani V, Soler M, Rivas M, Torres AG (2012) Development of a multiplex PCR assay for detection of Shiga toxin-producing Escherichia coli, enterohemorrhagic E. coli, and enteropathogenic E. coli strains. Front Cell Infect Microbiol 2(8):1-10

Chen I, Dubnau D (2004) DNA uptake during bacterial transformation. Nat Rev Microbiol 2:241-249

Cone RW, Hobson AC, Huang MW (1992) Co-amplified positive control detects inhibition of polymerase chain reactions. J Clin Microbiol 30:3185-3189

Contreras CA, Ochoa TJ, Ruiz J, Lacher DW, Rivera FP, Saenz Y, Chea-Woo E, Zavaleta N, Gil AI, Lanata CF, Huicho L, Maves RC, Torres C, DebRoy C, Cleary TG (2011) Phylogenetic 
relationships of Shiga toxin-producing Escherichia coli isolated from Peruvian children. J Med Microbiol 60:639-646

Feng PCH, Jinneman K, Scheutz F, Monday SR (2011) Specificity of PCR and serological assays in the detection of Escherichia coli shiga toxin subtypes. Appl Environ Microbiol 77(18):6699-6702

Grabow WOK, Müller EE, Ehlers MM, de Wet CME, Uys M, Clay CG (2003) Occurrence in water sources of E. coli 0157:H7 and other pathogenic E. coli strains, Water Research Commission report No.: 1068/1/03, ISBN No.: 1-86845-988-8

Grape M, Motakefi A, Pavuluri S, Kahlmeter G (2007) Standard and real-time multiplex PCR methods for detection of trimethoprim resistance dfr genes in large collections of bacteria. Clin Microbiol Infect 13:1112-1118

Hacker J, Kaper JB (2000) Pathogenicity islands and the evolution of microbes. Annu Rev Microbiol 54:641-679

Hartman LJ, Coyne SR, Norwood DR (2005) Development of a novel internal positive control for Taqman based assays ${ }^{\circledR}$. Mol Cell Probes 19:51-59

Hidaka A, Hokyo T, Arikawa K, Fujihara S, Ogasawara J, Hase A, Hara-Kudo Y, Nishikawa Y (2009) Multiplex real-time PCR for exhaustive detection of diarrhoeagenic Escherichia coli. J Appl Microbiol 106:410-420

Horokova K, Mlejnkova H, Mlejnek P (2008) Specific detection of Escherichia coli isolated from water samples using polymerase chain reaction targeting four genes: cytochrome bd complex, lactose permease, B-D-glucuronidase, and B-D-galactosidase. J Appl Microbiol 105:970-976

Hsu S-C, Tsen H-Y (2001) PCR primers designed from malic acid dehydrogenase gene and their use for detection of Escherichia coli in water and milk samples. Int J Food Microbiol 64:1-11

Iijima Y, Miki K, Kanamori S, Toyokawa M, Asari S (2007) Evaluation of colony-based examinations of diarrhoeagenic E. coli in stool specimens: low probability of detection because of low concentrations, particularly during the early stage of gastroenteritis. Diagn Microbiol Infect Dis 58:303-308

Kaper JB, Nataro JP, Mobley HLT (2004) Pathogenic Escherichia coli. Nat Rev Microbiol 2:123-140

Kenny B, Abe A, Stein M, Finlay BB (1997) Enteropathogenic Escherichia coli protein secretion is induced in response to conditions similar to those in the gastrointestinal tract. Infect Immun 65(7):2606-2612

Kimata K, Shima T, Shimizu M, Tanaka D, Isobe J, Gyobu Y, Watahiki M, Nagai Y (2005) Rapid categorization of pathogenic Escherichia coli by multiplex PCR. Microbiol Immunol 49(6):485-492

López-Saucedo C, Cerna JF, Villegas-Sepulveda N, Thompson R, Velazquez FR, Torres J, Tarr PI, Estrada-Garcia T (2003) Single multiplex polymerase chain reaction to detect diverse loci associated with diarrheagenic Escherichia coli. Emerg Infect Dis 9(1):127-131

Mbene AB, Houreld NN, Abrahamse H (2009) DNA damage after phototherapy in wounded fibroblast cells irradiated with $16 \mathrm{~J} /$ $\mathrm{cm}^{2}$. J Photochem Photobiol 94:131-137
Moses AE, Garbati MA, Egwu AO, Ameh EJ (2006) Detection of E. coli 0157 and 026 serogroups in human immunodeficiency virus-infected patients with clinical manifestation of diarrhoea in Maiduguri, Nigeria. Research Journal of Medicine and Medical Sciences 1(4): 140-145

Müller EE, Ehlers MM, Grabow WOK (2001) The occurrence of E. coli 0157:H7 in South African water sources intended for direct and indirect human consumption. Water Res 35(13):3085-3088

Omar KB, Barnard TG, Jagals P (2010) Development of a competitive PCR assay for the quantification of total Escherichia coli DNA in water. Afr J Biotechnol 9(4):564-572

Pass MA, Odedra R, Batt RM (2000) Multiplex PCR for identification of Escherichia coli virulence genes. J Clin Microbiol 38:2001-2004

Presterl E, Zwick RH, Reichmann S, Aichelburg A, Winkler S, Kremsner PG, Graninger W (2003) Frequency and virulence properties of diarrheagenic Escherichia coli in children with diarrhoea in Gabon. Am J Trop Med Hyg 69(4):406-410

Sabat G, Rose P, Hickey WJ, Harkin JM (2000) Selective and sensitive method for PCR amplification of Escherichia coli $16 \mathrm{~S}$ rRNA genes in soil. Appl Environ Microbiol 66(2):844-849

Shieh Y-SC, Wait D, Tai L, Sobsey MD (1995) Methods to remove inhibitors in sewage and other faecal wastes for enterovirus detection by the polymerase chain reaction. J Virol Methods 54:51-66

Soto SM, Guiral EG, Vila BJ (2009) Prevalence of the set-1B and astA genes encoding enterotoxins in uropathogenic Escherichia coli clinical isolates. Microb Pathog 47:305-307

Standard Methods (2005) For the examination of water and wastewater, 21st edn, Edited by Eaton AD, Clesceri LS, Rice EW and Greenberg AE. Washington, USA

Tarr CL, Large TM, Moeller CL, Lacher DW, Tarr PI, Acheson DW, Whittam TS (2002) Molecular characterization of a serotype 0121:H19 clone, a distinct shiga toxin-producing clone of pathogenic Escherichia coli. Infect Immun 70(12):6853-6859

Vidal M, Kruger E, Durán C, Lagos R, Levine M, Prado V, Toto C, Vidal R (2005) Single multiplex PCR assay to identify simultaneously the six categories of diarrheagenic Escherichia coli associated with enteric infections. J Clin Microbiol 43(10):5362-5365

Wilson AG (1997) Inhibition and facilitation of nucleic acid amplification. Appl Environ Microbiol 63(10):3741-3751

Wu XY, Chapman T, Trott DJ, Bettelheim K, Do TN, Driesen S, Walker MJ, Chin J (2007) Comparative analysis of virulence genes, genetic diversity, and phylogeny of commensal and enterotoxigenic Escherichia coli isolates from weaned pigs. Appl Environ Microbiol 73(1):83-91

Yatsuyanagi J, Saito S, Miyajima Y, Amano KI, Enomoto K (2003) Characterization of atypical Enteropathogenic Escherichia coli strains harbouring the astA gene that were associated with a waterborne outbreak of diarrhoea in Japan. J Clin Microbiol 41(5):2033-2039 